\title{
Study of age factor of concrete upto 180 days
}

\author{
Mr. Mayur Ashok Jadhav ${ }^{1}$,Dr. V. M. Inamdar ${ }^{2}$ \\ ${ }^{1}$ (M.E. IInd Year, Department of Civil Engineering, G.H. Raisoni College of Engineering and Management, \\ Savitribai Phule Pune University) \\ ${ }^{2}$ (Former Professor, Department of Civil Engineering, G.H. Raisoni College of Engineering and Management, \\ Savitribai Phule Pune University \& Presently Professor, Department of Applied Mechanics, Walchand College \\ of Engineering, Sangli, Maharashtra, India )
}

\begin{abstract}
This paper deals with the effective utilization of waste material in concrete production as a partial replacement for Cement. Concrete is the most widely used construction material in civil engineering industry because of its high structural strength and stability. The concrete industry is looking for supplementary cementitious material or industrial by product with the objective of reducing the carbon dioxide emission which is harmful to environment which is produced by cement manufacturing company. In this experimental work the cement has been replaced by GGBS and Fly ash in the range of 20\% and 30\% by weight of cement for M20 grade mix. Compressive strength test was carried out for 7, 28, 56 and 90 days of curing period.
\end{abstract}

Keywords: Ground Granulated Blast Furnace Slag (GGBS), Compressive Strength.

\section{Introduction}

Now a day the world is witnessing the construction of very challenging and difficult structures, concrete being the most important and widely used structural material is called upon to possess very high strength. The main ingredient in the conventional concrete is Portland cement. The amount of cement production emits approximately equal amount of carbon dioxide into the atmosphere. Cement production is consuming significant amount of natural resources. To overcome the above ill effects, the advent of newer material and construction techniques and in this drive, admixture has taken newer things with various ingredients has become a necessity. The addition of pozzolanic materials with OPC a century old practice is an alternative in the construction industry.

\subsection{Fly Ash:}

Now a day the world is witnessing the construction of very challenging and difficult structures, concrete being the most important and widely used structural material is called upon to possess very high strength. The main ingredient in the conventional concrete is Portland cement. The amount of cement production emits approximately equal amount of carbon dioxide into the atmosphere. Cement production is consuming significant amount of natural resources. To overcome the above ill effects, the advent of newer material and construction techniques and in this drive, admixture has taken newer things with various ingredients has become a necessity. The addition of pozzolanic materials with OPC a century old practice is an alternative in the construction industry. Fly ash one of the byproducts of thermal power plants is one of the most common mineral admixture used in concrete worldwide. Fly ash largely improves the durability of concrete. One of the greatest drawbacks while using fly ash as pozzolanic material in concrete is the early age performance of concrete. The early age strength development of fly ash blended binary concretes shows poor performance than the ordinary concrete.

\subsection{Ground Granulated Blast Furnace Slag:}

Ground Granulated Blast Furnace is a byproduct from the Blast furnace slag is a solid waste discharged in large quantities by the iron and steel industry in India. These operate at a temperature of about 1500 degree centigrade and are fed with a carefully controlled mixture of iron - ore, coke and limestone. The iron ore is reduced to iron and remaining materials from slag that floats on top of the iron. This slag is periodically tapped off as a molten liquid and if it is to be used for the manufacture of GGBS it has been rapidly quenched in large volumes of water. The quenching optimizes the cementitious properties and produces granules similar to coarse sand. This granulated slag is then dried and ground to a fine powder. The re-cycling of these slag's will become an important measure for the environmental protection. Iron and steel are basic materials that underpin modern civilization, and due to many years of research the slag that is generated as a by production iron and steel production is now in use as a material in its own right in various sectors. The primary constituents of slag are lime $(\mathrm{CaO})$ and silica $(\mathrm{SiO} 2)$. Portland cement also contains these constituents. The primary constituent of slag is soluble in water and exhibits an alkalinity like that of cement or concrete. Meanwhile, with the development 
of steel industry, the disposal of such a material as a waste is definitely a problem and it may cause severe environmental hazards.

\subsection{Aim:-}

To study the compressive strength of concrete upto 180 days with partial replacement of Fly ash and GGBS with cement quantity.

\section{1,4 Objective:-}

i. To study the variation of compressive strength concrete with respect to age.

ii. To study the comparison between Plain cement concrete, fly ash cement concrete and GGBS cement concrete with respect to compressive strength.

\section{Methodology}

i. To determine the mix design for M20 grade of concrete.

ii. Cast a no. of cubes for following combination:

i. Use of $100 \%$ cements content in mix design.

ii. Use of Cement $(80 \%)+$ Fly ash(20\%) in the mix design.

iii. Use of Cement $(70 \%)+$ Fly ash(30\%) in the mix design.

iv. Use of Cement $(80 \%)+$ GGBS(20\%) in the mix design.

v. Use of Cement(70\%)+ GGBs(30\%) in the mix design.

iii. Testing of Concrete cubes on 28th, 56th, 90th, 120th day.

iv. Comparison of above result.

\section{Experimental Work}

Mix No.1: Use of $100 \%$ cement content in mix design:

Material:

A. Cement - Ordinary Portland cement of 53 grade confirming to IS: 12269-1987 used in the investigation

B. Fine aggregate - Crush sand confirming to Zone-II used as fine aggregate.

C. Coarse Aggregate - Locally available crushed angular coarse aggregates of size $20 \mathrm{~mm}$ and $10 \mathrm{~mm}$ with specific gravity of 2.7 was used as Coarse aggregate

D. GGBS - Confirming to IS 12089:1981

E. HVFA - High Volume Fly Ash as per the laboratory test conducted according to ASTM method C1202

F. Water - Locally available potable water confirming to IS 456-2000 is used

\begin{tabular}{|c|c|c|}
\hline Materials & For 1 cum in $\mathrm{kg}$ & For 6 cubes in $\mathrm{kg}$ \\
\hline W/C & 0.5 & $\ldots$ \\
\hline Cement & 300 & 7.5 \\
\hline Fly Ash & $\ldots$ & $\ldots$ \\
\hline GGBS & $\ldots$ & $\ldots$ \\
\hline 20mm Aggregate & 619 & 15.47 \\
\hline 10mm Aggregate & 446 & 11.15 \\
\hline Crush Sand & 912 & 22.8 \\
\hline Water & 175 & 4.375 \\
\hline Admixture(1\%) & 3.15 & 0.078 \\
\hline
\end{tabular}

Mix No.2: Use of Cement $(80 \%)+$ Fly ash(20\%) in the mix design:

\begin{tabular}{|c|c|c|}
\hline Materials & For 1 cum in $\mathrm{kg}$ & For 6 cubes in $\mathrm{kg}$ \\
\hline W/C & 0.5 & $\ldots$ \\
\hline Cement & 240 & 7.5 \\
\hline Fly Ash & 60 & 6.0 \\
\hline GGBS & $\ldots$ & $\ldots$ \\
\hline 20mm Aggregate & 619 & 15.47 \\
\hline 10mm Aggregate & 446 & 11.15 \\
\hline Crush Sand & 912 & 22.8 \\
\hline Water & 175 & 4.375 \\
\hline Admixture(1\%) & 3.15 & 0.078 \\
\hline
\end{tabular}

Mix No.3: Use of Cement(70\%)+ Fly ash(30\%) in the mix design:

\begin{tabular}{|c|c|c|}
\hline Materials & For 1 cum in kg & For 6 cubes in $\mathrm{kg}$ \\
\hline W/C & 0.5 & $\ldots$ \\
\hline Cement & 210 & 5.25 \\
\hline Fly Ash & 90 & 2.25 \\
\hline GGBS & $\ldots$ & $\ldots$ \\
\hline
\end{tabular}




\begin{tabular}{|c|c|c|}
\hline 20mm Aggregate & 619 & 15.47 \\
\hline 10mm Aggregate & 446 & 11.15 \\
\hline Crush Sand & 912 & 22.8 \\
\hline Water & 175 & 4.375 \\
\hline Admixture(1\%) & 3.15 & 0.078 \\
\hline
\end{tabular}

Mix No.4: Use of Cement( $80 \%)+$ GGBS(20\%) in the mix design:

\begin{tabular}{|c|c|c|}
\hline Materials & For 1 cum in $\mathrm{kg}$ & For 6 cubes in $\mathrm{kg}$ \\
\hline W/C & 0.5 & $\ldots$ \\
\hline Cement & 240 & 7.5 \\
\hline Fly Ash & $\ldots$ & $\ldots$ \\
\hline GGBS & 60 & 6.0 \\
\hline 20mm Aggregate & 619 & 15.47 \\
\hline 10mm Aggregate & 446 & 11.15 \\
\hline Crush Sand & 912 & 22.8 \\
\hline Water & 175 & 4.375 \\
\hline Admixture(1\%) & 3.15 & 0.078 \\
\hline \multicolumn{2}{|r|}{} \\
\hline
\end{tabular}

Mix No.5: Use of Cement(70\%)+ GGBS(30\%) in the mix design:

\begin{tabular}{|c|c|c|}
\hline Materials & For 1 cum in kg & For 6 cubes in kg \\
\hline W/C & 0.5 & $\ldots$ \\
\hline Cement & 210 & 5.25 \\
\hline Fly Ash & $\ldots$ & $\ldots$ \\
\hline GGBS & 90 & 2.25 \\
\hline 20mm Aggregate & 619 & 15.47 \\
\hline 10mm Aggregate & 446 & 11.15 \\
\hline Crush Sand & 912 & 22.8 \\
\hline Water & 175 & 4.375 \\
\hline Admixture(1\%) & 3.15 & 0.078 \\
\hline
\end{tabular}

IV. Results

\begin{tabular}{|c|c|c|c|c|c|c|c|c|c|c|}
\hline \multirow[t]{2}{*}{$\begin{array}{c}\text { Day of } \\
\text { Test }\end{array}$} & \multicolumn{2}{|c|}{$100 \%$ cement content } & \multicolumn{2}{|c|}{$\begin{array}{c}\text { Cement }(80 \%)+\text { Fly } \\
\operatorname{ash}(20 \%)\end{array}$} & \multicolumn{2}{|c|}{$\begin{array}{c}\text { Cement }(70 \%)+\text { Fly } \\
\operatorname{ash}(30 \%)\end{array}$} & \multicolumn{2}{|c|}{$\begin{array}{c}\text { Cement( } 80 \%)+ \\
\text { GGBS(20\%) }\end{array}$} & \multicolumn{2}{|c|}{$\begin{array}{c}\text { Cement(70\%)+ } \\
\text { GGBS(30\%) }\end{array}$} \\
\hline & $\begin{array}{c}\text { Compressive } \\
\text { Strength in } \\
\text { Mpa }\end{array}$ & $\begin{array}{c}\text { Average } \\
\text { strength } \\
\text { Mpa }\end{array}$ & $\begin{array}{c}\text { Compressive } \\
\text { Strength in } \\
\text { Mpa }\end{array}$ & $\begin{array}{c}\text { Average } \\
\text { strength } \\
\text { Mpa }\end{array}$ & $\begin{array}{c}\text { Compressive } \\
\text { Strength in } \\
\mathrm{Mpa}\end{array}$ & $\begin{array}{c}\text { Average } \\
\text { strength } \\
\text { Mpa }\end{array}$ & $\begin{array}{c}\text { Compressive } \\
\text { Strength in } \\
\text { Mpa }\end{array}$ & $\begin{array}{c}\text { Average } \\
\text { strength } \\
\text { Mpa }\end{array}$ & $\begin{array}{c}\text { Compressive } \\
\text { Strength in } \\
\text { Mpa }\end{array}$ & $\begin{array}{c}\text { Average } \\
\text { strength } \\
\mathrm{Mpa}\end{array}$ \\
\hline $28^{\text {th }}$ day & 26.32 & & 20.00 & & 23.55 & & 24.88 & & 26.22 & \\
\hline $28^{\text {th }}$ day & 21.33 & 23.7 & 23.11 & 21.62 & 21.33 & 23.7 & 21.77 & 23.25 & 22.67 & 25.18 \\
\hline $28^{\text {th }}$ day & 23.55 & & 21.77 & & 26.22 & & 23.11 & & 26.67 & \\
\hline $56^{\text {th }}$ day & 27.11 & & 22.22 & & 25.77 & & 27.11 & & 28.88 & \\
\hline $56^{\text {th }}$ day & 25.77 & 27.10 & 24.00 & 23.99 & 23.55 & 24.44 & 24.00 & 25.62 & 26.22 & 28.29 \\
\hline $56^{\text {th }}$ day & 28.44 & & 25.77 & & 24.00 & & 25.77 & & 29.77 & \\
\hline $90^{\text {th }}$ day & 29.33 & & 23.55 & & 27.11 & & 29.33 & & 31.55 & \\
\hline $90^{\text {th }}$ day & 27.55 & 29.18 & 25.77 & 25.47 & 28.00 & 27.11 & 30.22 & 29.03 & 30.66 & 31.55 \\
\hline $90^{\text {th }}$ day & 30.66 & & 27.11 & & 26.22 & & 27.55 & & 32.44 & \\
\hline
\end{tabular}

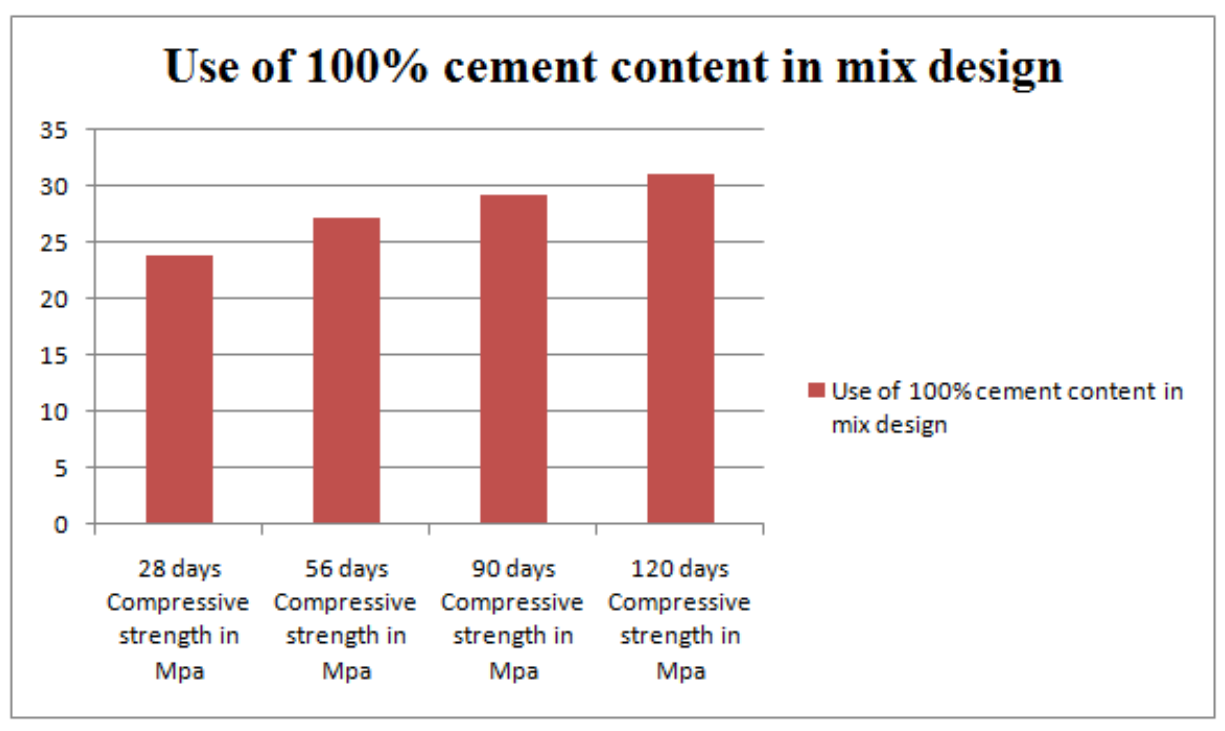



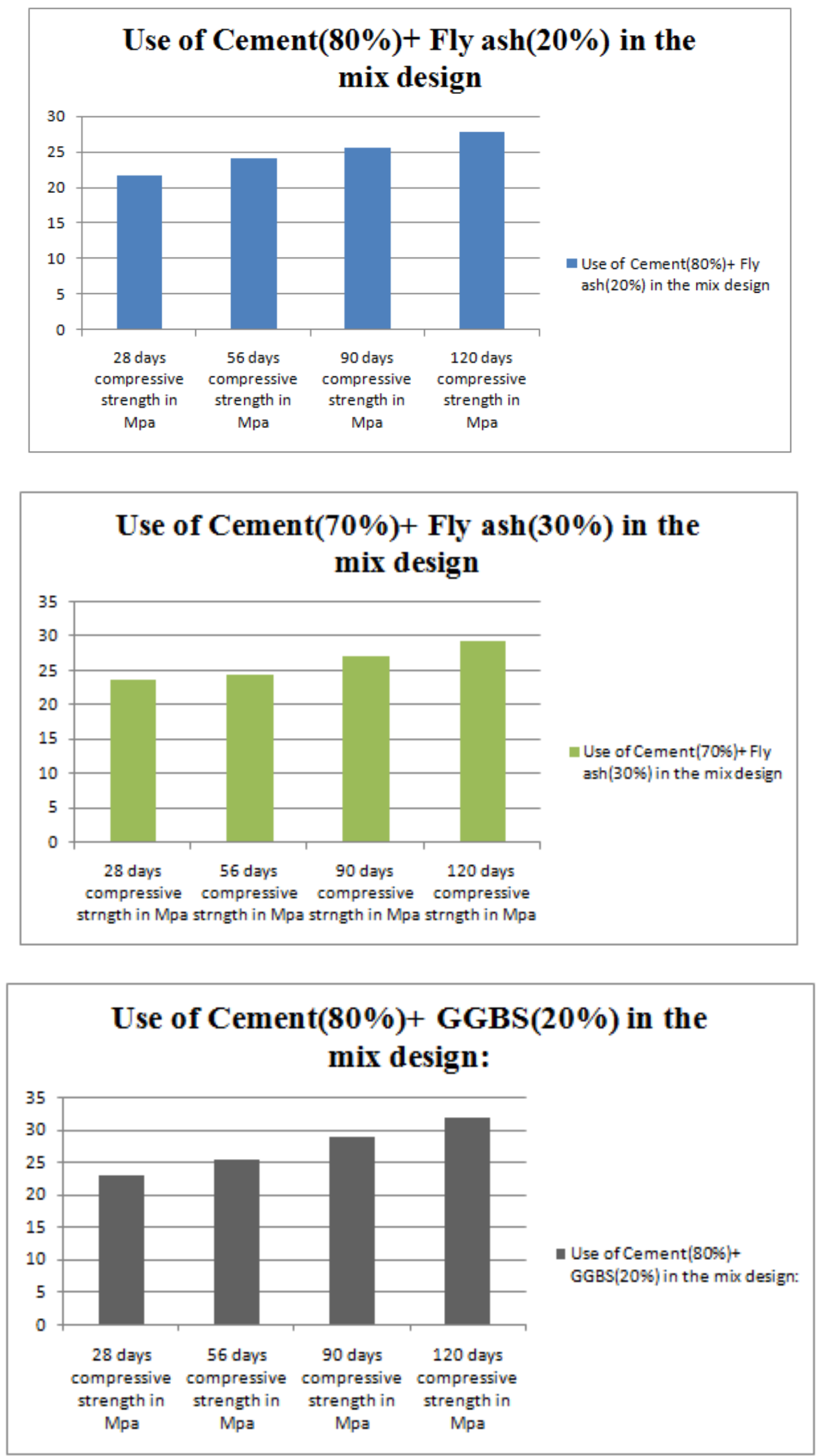


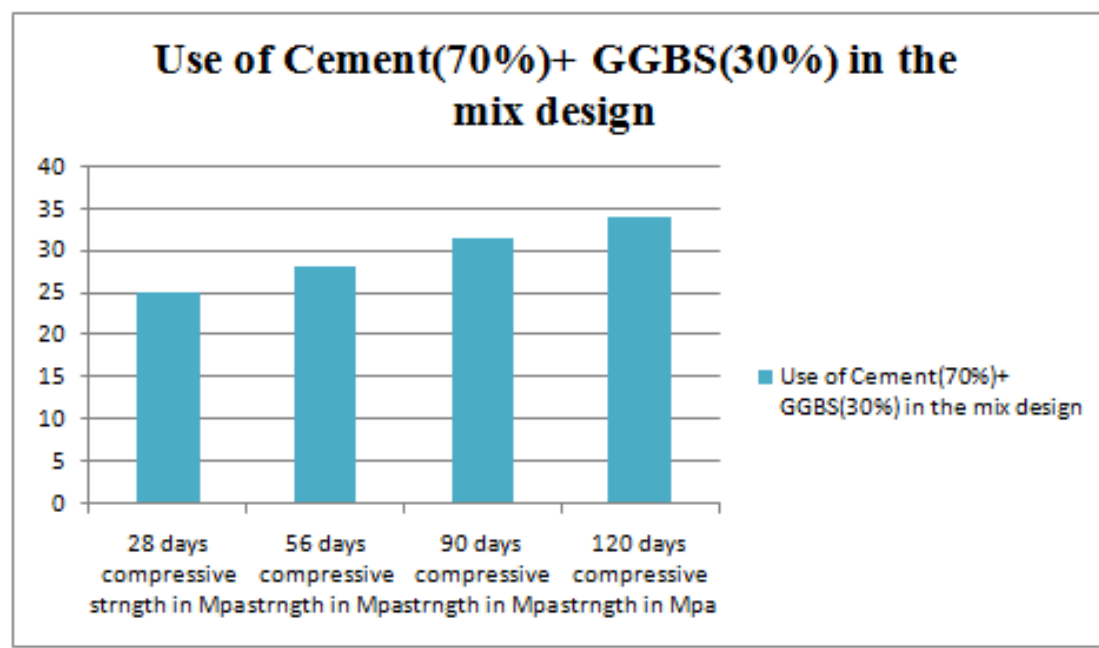

Comparison of Result:

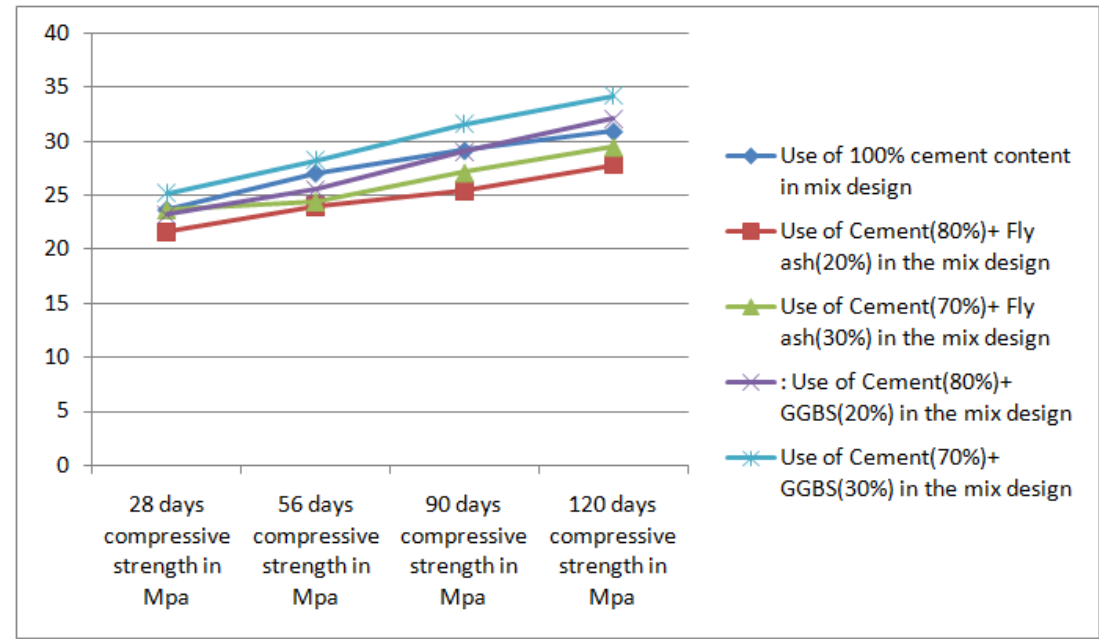

\section{Conclusion}

From the above Experimental work we can say that, in initial 28 days all 5 mixes achieved $100 \%$ compressive strength. After $56,90 \& 120$ th day compressive strength was increasing with respect to age of concrete. Hence from the above result can say the partial replacement of Fly Ash $(20 \%$ \& 30\%)\& GGBS (20\% \&30\%) with cement is effective and can be use actually on site in M20 grade of concrete. From the Enviromental point of view it is very importat to use fly ash(waste from Thermal power plant) and GGBS (Waste from iron \& steel Industry) \& this problem can also be solve by using this products in concrete by partial replacement.

\section{Acknowledgement}

I have great pleasure to express my deep sense of gratitude and sincere regards to my guide Dr. V. M. Inamdar, for his guidance and friendly discussion which helped me immensely in selecting this topic. His generous encouragement throughout my dissertation work helped me in completing this project work. I would like to thank our Head of Civil Engineering Department Prof. N.C. Dubey for allowing me to do this project. He has immensely helped in providing all opportunities and facilities for the project work. I am thankful to all the faculty members of Civil Engineering and library staff for helping me in this work. Finally, I would like to thank all those who directly or indirectly helped me during my work.

\section{References}

[1]. D.audinarayana, P. sarika and ,Dr. P Sravana.Studies on Compressive Strengrth of Ternary Blended concretes at different water binder ratios. AJER, 2013

[2]. Bollineni Niithin Krishna,M. Arvind, Experimental and Analytical study on High strength concrete beams under flexure ,2015.

[3]. Peter Claisse,Christopher Dean, Compressive strength of concrete after early loading .Institute of civil engineers,UK,2012.

[4]. Chaitra H L, Pramod K, An Experimental study on partial replacement of cement by GGBS and natural sand by quarry sand in concrete, 2015 . 